\title{
FIRST NESTING RECORD AND STATUS OF THE CLARK'S GREBE IN CANADA
}

KEN. D. DE SMET, Box 184, Group 550, R.R. 5, Winnipeg, Manitoba. R2C $2 Z 2$

The existence of two color phases of the Western Grebe (Aechmorphorus occidentalis) has been known for over 100 years. Although Baird referred to the light-phased birds as Podiceps clarkii as early as 1858 , most ornithologists regarded them as color phases of the Western Grebe. ${ }^{12}{ }^{14}$ More recently, the two forms have been found to be reproductively isolated to a large extent and several isolating mechanisms have been identified. 8119 The American Ornithologists' Union recently assigned separate species status to the light-phased birds, calling them the Clark's Grebe (Aechmorphorus clarkii). ${ }^{1}$

The breeding distribution of the Western Grebe extends along the Pacific Coast from northwestern Alberta and south-central British Columbia to southcentral Mexico, and east to Manitoba, Minnesota and Colorado. 'The Clark's Grebe co-exists with the Western Grebe throughout much of this range, but relative frequencies of the Clark's Grebe vary from less than $1 \%$ of the population in Canada and in eastern portions of the range, to $12-18 \%$ in Utah, and to more than $50 \%$, occasionally up to $90 \%$, in California and Mexico. ${ }^{13} 1113412$

In Canada, Godfrey listed the Clark's Grebe as a probable breeder in southern Manitoba, Saskatchewan and Alberta and a possible breeder in British Columbia. ${ }^{5}$ Although summer records suggest that the species nests in Canada, no nesting evidence has been reported (W.E. Godfrey person comm.). During several years of field work on the Western Grebe in the Delta Marsh and Marshy Point regions of Manitoba during the late 1970s, Neuchterlein observed that much less than $1 \%$ of the population consisted of Clark's Grebes (pers. comm.). He observed two mixed pairs nesting at Marshy Point, one involving a Western Grebe male and a hybrid female. ${ }^{9}$ During midJune 1986, he observed a pair of Clark's Grebes near the end of Cook's Creek in the Delta Marsh, his first observation of a mated pair in Manitoba. The only other accepted record of the Clark's Grebe in Manitoba was a lone bird observed at Natalie Lake near Pinawa on 3 May 1986 by a large group of knowledgeable observers (R. Koes, pers. comm.).

In Saskatchewan, Clark's Grebees have been reported from three sites: five were observed among 500 nesting Western Grebes at Old Wives Lake in 1957; two were seen on 17 May - 1 June 1985 by numerous observers and one was spotted by several observers on 22 July 1986 at Wascana Marsh in Regina, and Wayne Harris (pers. comm.) has observed Clark's Grebes in a Western Grebe colony at the north end of Last Mountain Lake during several years. 1067 Harris indicated that an adult Clark's Grebe with young was observed on one occasion, but its mate was not seen. Although the Clark's Grebe is considered more common in western North America, there are no definite reports for Alberta (Bruce McGillivray, pers. comm.). In British Columbia, there are two accepted records: one observed by several observers at Boundary Bay on 8 December 1986 and one seen by numerous observers and photographed (Photo \#142, B.C. Prov. Museum) at Ogden Point, Victoria, on 13-26 October 1986. ${ }^{2}$ Unofficial reports from Duck Lake in the Creston Wildlife Management Area suggest that $10 \%$ of the population is com 
prised of Clark's Grebes (L.S. Forbes, pers. comm.). Forbes also observed a mixed pair feeding a chick on 26 July 1983 . The Western Grebe is a fairly common nesting species in large lakes and marshes of southern Manitoba. Nowhere is the species more readily observed, however, than along PTH 23 on the north shore of Pelican Lake. On several occasions during the last two years I have scanned portions of this colony attempting to locate a Clark's Grebe, without success. During 1986, nesting was delayed until late June, when the grebes finally began establishing a colony in shoreline emergents in the northwest corner of the lake. Because this site was immediately south of the town of Ninette, some residents were presented with the unique opportunity of observing Western Grebes nesting almost in their back yards - within 75 meters of their houses!

At 5:00 p.m. on 25 June 1986, Ted Grewe and myself drove to the Ninette boat launch, just west of the colony, with the intention of collecting one egg from each of ten Western Grebe nests for toxic chemical analysis. After briefly scanning the grebes outside the colony, I donned chest-waders and headed into the emergents. As I approached the colony, the first nesting grebe I saw had white extending well over the eye, and a bright orange bill. There could be no doubt it was a Clark's Grebe. I retraced my steps to get a camera and proceeded back to the colony. Upon my second approach the nesting adult was more wary, but during the next half hour I was able to get several photos of it swimming in open water near the nest (Fig. 1). During this time it chased off several Western Grebes and a second pair of Clark's Grebes that was attempting to establish a nesting territory nearby. Although I originally observed only one of the nesting adults, we observed two adult Clark's Grebes at the nest one hour later, one incubating the eggs and its mate right beside it.

The Clark's Grebe nest was located in waist-deep $(90 \mathrm{~cm})$ water and looked much like nearby Western Grebe nests. The structure was floating and attached to bulrushes (Scirpus spp.). The base of the nest consisted of green bulrush stems, with an inside cup of bulrushes and submergent vegetation. The clutch consisted of three uncovered and unstained eggs, hence it was believed to be incomplete. The remainder of the colony consisted of about 500 adults. There were approximately 100 Western Grebe nests with eggs and an equal number of empty nests. Most of the clutches consisted of one or two eggs, about 10 nests had three eggs and 2 had four eggs. As I walked through the colony, I saw several Grebes that looked like hybrids, but no more Clark's Grebes were observed.

During the next 2 weeks many bird watchers viewed one or more of the Clark's Grebes at this site. Harvey Lane and Dennis Fast also observed two Clark's Grebes feeding with Western Grebes in the northeast corner of the lake and a third grebe that was presumed to be a hybrid (pers. comm.). From close range through a spotting scope they noted that they hybrid-like grebe had the black and white facial margin horizontally bisecting the eye and an intermediate-colored (orangish-yellow) bill. Photos I had taken near the colony also revealed at least two intermediatecolored grebes. One resembled a Western Grebe but had a large white patch in front of each eye (Fig. 2). The second was photographed from a distance, revealing whitish lores, whitish-grey above and behind the eye, and a bill that appeared orange in comparison to nearby Western Grebes. The white in the lores of each of these birds suggests hybridization as Storer and Neuchterlein wrote "breeding adults showed a complete segregation by color phase in the color of the lores. Dark-phase birds all had dark or light gray lores." 14 Although Ratti indicated that hybridization was rare, Neuchterlein speculated that it occurs more commonly in the north where the Clark's Grebe is rare and the species-specific response to the unique 

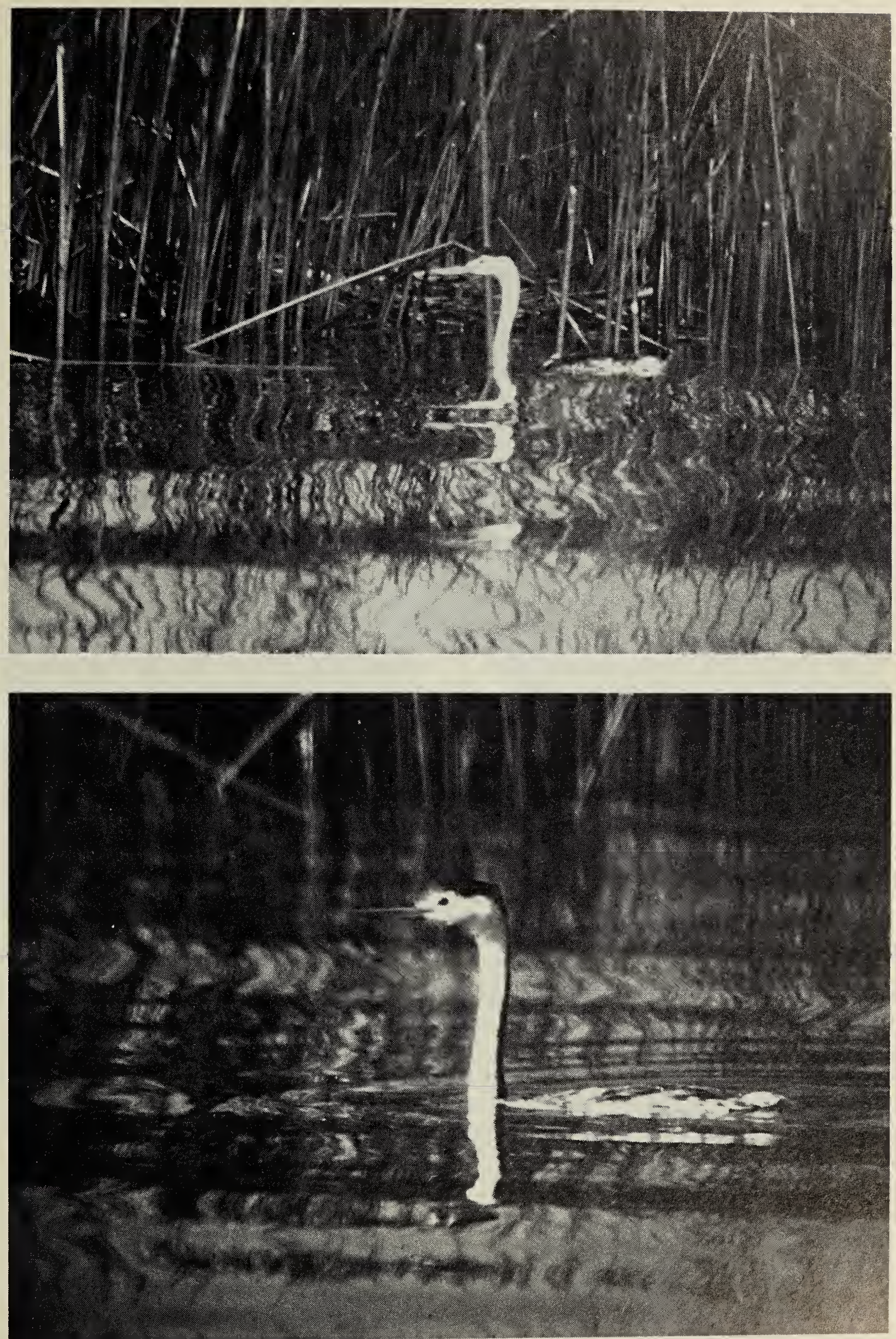

Figure 1. Clark's Grebe near nest (upper); second Clark's Grebe (lower).

Ken De Smet 


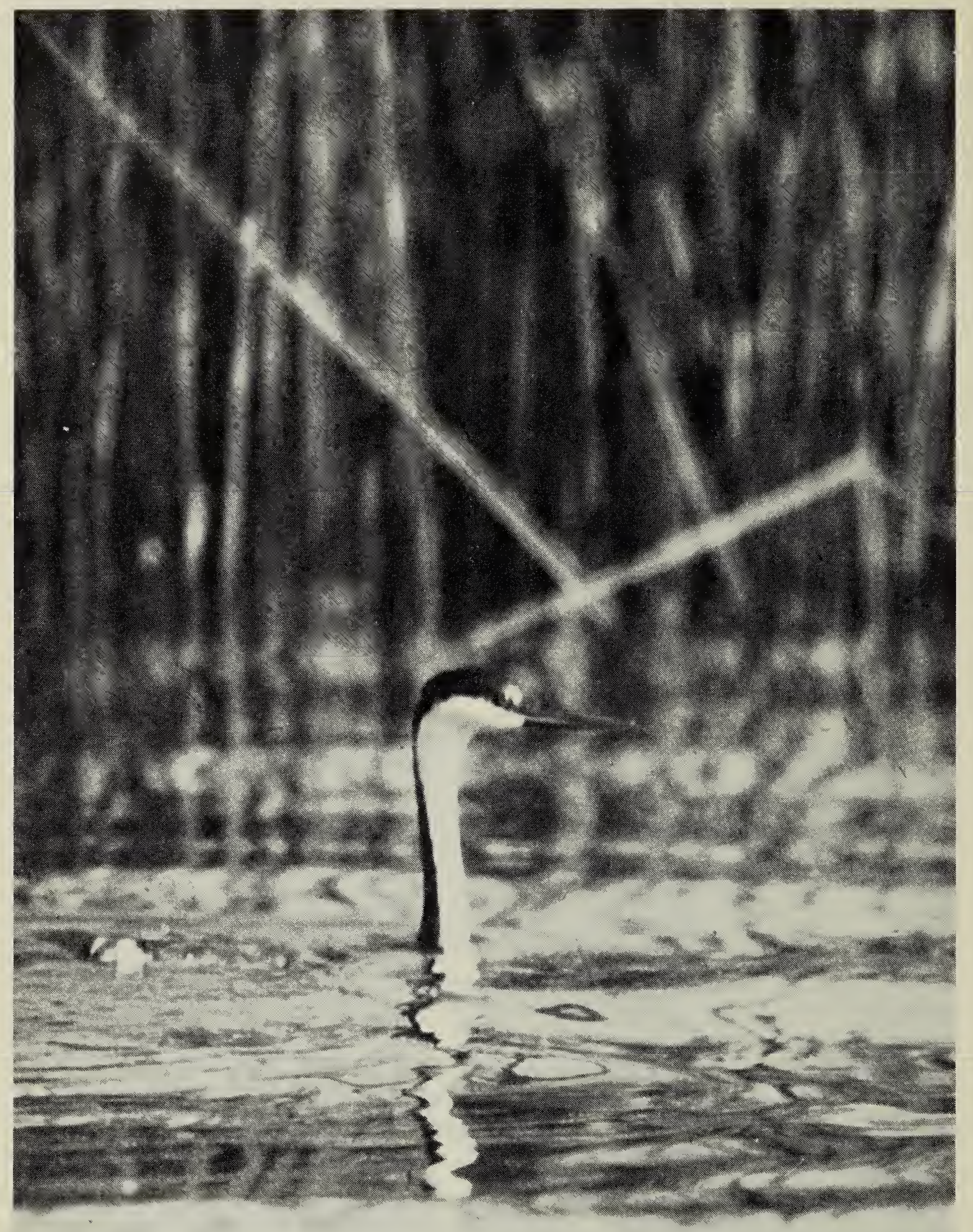

Figure 2. Hybrid Western X Clark's Grebe at Pelican Lake, Manitoba.

Ken De Smet 
Advertising Call of the two species is lowered. ${ }^{11} 9$

A visit to the colony on 23 July revealed that the Clark's Grebe nest was empty, the eggs presumably hatched. Eight-six nests were still active, however, including 17 with one egg, 32 with two, 25 with three, 7 with four, and 5 with five eggs. Initially, one pair of Clark's Grebes, presumably nonbreeders, was seen resting outside the colony. Although no Clark's Grebes were observed within the emergents, one was observed just outside. This bird was probably mated and nesting with a Western Grebe as both birds swam together and performed vocal duets while I conducted the nest checks.

The above information suggests that at least five Clark's Grebe adults were present at Pelican Lake during 1986. One pair nested, a second pair did not nest or was unsuccesful, and a fifth Clark's Grebe probably mated and nested with a Western Grebe. Several adults were observed that were presumed to be hybrids. Although about $1 \%$ of the Western Grebe populations at Pelican Lake, Manitoba, and Old Wives Lake, Saskatchewan were composed of Clark's Grebes when these colonies were observed, it is probable that most Western Grebe colonies in Canada, at least in the eastern portion of its range, contain much less than 1\% Clark's Grebes. Western Grebe colonies throughout Canada need to be more carefully scrutinized to better understand the status and distribution of the Clark's Grebe.

1 A.O.U. 1985. Thirty-fifth supplement to the American Ornithologists' Union check-list of North American birds. Auk 102:680-686.

2 CAMPBELL, R.W., N.K. DAWE, J.M. COOPER, G.W. KISER, M. MCNALL and I. MCTAGGERT-COWAN. In prep. Birds of British Columbia: Non passerines. B.C.
Prov. Museum.

3 DICKERMAN, R.W. 1963. The grebe Aechmophorus occidentalis clarkii as a nesting bird of the Mexican Plateau. Condor 65:66-67.

4 DICKERMAN, R.W. 1973. Further notes on the Western Grebe in Mexico. Condor 75:131-132.

5 GODFREY, W.E. 1986. The Birds of Canada, revised ed. National Museum of Natural Sciences, Ottawa. 595 pp.

6 GOLlOP, J.B. 1985. The spring season: Prairie Provinces region. Am. Birds 39:315-317.

7 GOLLOP, J.B. 1986. The nesting season: Prairie Provinces region. Am. Birds 40:1218-1219.

8 LINDVALL, M.L. 1976. Breeding biology and pesticide PCB contamination of Western Grebe at Bear River Migratory Bird Refuge, Utah. Unpubl. M. Sc. thesis, Utah State Univ., Logan, Utah.

9 NEUCHTERLEIN, G.L. 1981. Courtship behavior and reproductive isolation between Western Grebe color morphs. Auk 98:335-349.

10 PALMER, R.S. 1962. Handbook of North American birds. Yale University Press, New Haven and London.

11 RATTI, J.T. 1979. Reproductive separation and isolating mechanisms between sympatric dark- and light-phase Western Grebes. Auk 96:573-586.

12 RATTI, J.R. 1986. Identification and distribution of Clark's Grebe. Loon 58:112-116.

13 STORER, R.W. 1965. The color phases of the Western Grebe. Living Bird 4:59-63.

14 STORER, R.W., and G.L. NEUCHTERLEIN. 1985. An analysis of plumage and morphological characters of the two color forms of the Western Grebe (Aechmorphorus). Auk 102:102-119. 